\title{
SOCIAL AND POLITICAL SENTIMENTS OF SCIENTIFIC AND PEDAGOGICAL WORKERS OF HIGHER SCHOOL OF UKRAINE IN THE PERIOD OF PARTIAL DEMOCRATIC CHANGES IN THE LATE 1950
}

\author{
Oksana Bulgakova \\ National University of Life and Environmental Sciences of Ukraine, Ukraine \\ semjons@apollo.lv
}

\begin{abstract}
Today, the activities of the scientific and pedagogical intelligentsia of Ukraine require in-depth study within the framework of social history, since the influence of teachers upon the young students as the country's intellectual capital is extremely important. The article states that the scientific and pedagogical intelligentsia of Ukraine actively reacted to the decisions of the XX Congress of the CPSU, which became an important stage in the condemnation of Stalinism and some democratic changes in the country. Based on archival sources about holding a closed meeting of the party activists in order to discuss N. Khrushchev's secret report, it was concluded that there are three main types of reaction to his speech: confusion, given the unclear prospects for the educational process; approval and desire to continue the decisive struggle against manifestations of the "personality cult"; expressing concern and inexpediency of disclosing information about repressions under the pretext of potential reputational losses for the country.
\end{abstract}

Keywords: higher school, intelligentsia, scientific workers, democratic changes.

\section{Introduction}

The growth of social and political activity of citizens of Ukraine in the last decade actualises the experience of social development in the historical periods of the past. Very valuable in this aspect is the so-called "Khrushchev thaw". After the death of J. Stalin and N. Khrushchev's report "On the personality cult and its consequences" the Ukrainian society became more active in search of a new paradigm of the social and political development. The Ukrainian intelligentsia, realising the need for changes, found itself among the driving forces of the "thaw" in the cultural sphere, and later, dissatisfied with the political course, became an important component of the movement of the sixtiers and dissidents. The scientific and pedagogical intelligentsia was a special part of the Soviet society and was in a difficult situation. The fulfillment of its functions by the scientific and pedagogical intelligentsia depended on the working conditions, mood, and everyday life, among which the teaching and educational function was one of the main ones. Its qualifications depended on the method of formation and the working conditions; and the material and living provision influenced the prestige of the teacher's status.

Today the activities of the scientific and pedagogical intelligentsia of Ukraine require in-depth study within the framework of social history, since the influence of teachers upon the young students as the country's intellectual capital is extremely important.

Analysis of the research into the history of the scientific and pedagogical intelligentsia of Ukraine in the Khrushchev period made it possible to distinguish three groups of research works: Soviet, modern Ukrainian and English-language studies. The image of the Soviet intelligentsia was generally positive. At the same time, some social characteristics of the scientific and pedagogical intelligentsia, asocial phenomena in its environment, manifestations of corruption, etc. remained outside the field of view of the researchers.

A well-known researcher of the intelligentsia of that period was the Ukrainian historian Yuri Kurnosov [1]. In addition to that, he examined the process of formation of the intelligentsia (specialists) starting from the students' circles, analysed the criteria for selecting students for universities; in his work, devoted to the ideological dissent in Ukraine in the 60s to first half of the 1980s, called the intelligentsia one of the driving forces of dissidence.

Their approaches to the study of the intelligentsia of the Soviet period are presented by modern Ukrainian historiography, namely by the works by Viktor Danilenko, Olga Kolyastruk, Oksana Prokhorenko, and others. Perception and reaction of the population of Ukraine to the XX Congress of the CPSU was studied in his works by Oleg Bazhan [2]. The everyday life of teachers of pedagogical universities of the Ukrainian SSR during the "thaw" was investigated by Alexander Lukyanenko [3]. Social history, namely the study of such a social stratum as the Soviet nomenclature, is being dealt with by the modern Ukrainian researcher Viktor Krupyna [4]. However, the available research on the 
intelligentsia does not reveal the fullness of its position. Today the departure from the class materialistic methodology allows to reveal new facets of this professional stratum.

The purpose of the study is to clarify the characteristic features of socio-political attitudes and reactions of the scientific and pedagogical intelligentsia of Ukraine as a separate socio-professional group to the XX Congress of the CPSU and other major fateful events, including in Hungary and Poland.

\section{Materials and methods}

The work was carried out mainly on the basis of the materials from the State Historical Archives of Ukraine. The descriptive method helped combine various plots into one, analytical text. By means of the problem-chronological method there was revealed the dynamics of the position of the scientific and pedagogical intelligentsia in the period studied.

There was also taken into account the experience of the formation and position of the scientific and pedagogical intelligentsia of Ukraine in the period after the First World War and before the Second World War. The chronological principle is used in this research work, which assumes the recognition of time and space as categories of the background meaning, significantly restraining from dealing with an unlimited set of facts, selecting them according to the place (Ukraine) and the time period (mid-1950s to first half of the 1960s).

The research is made by applying the principle of historicism, which determined that the scientific and pedagogical intelligentsia is considered in unique historical circumstances that developed during the investigated transitional period. Their uniqueness lies in the controlled "liberal turnaround", which turned out to be incomplete.

\section{Results and discussion}

Non-ordinary events in the history of a country always attract the attention of historians and intellectuals. To such landmark events should be referred also the 20th Congress of the CPSU, which took place in 1956. During its work on February 25 N. Khrushchev delovered a secret speech "On the personality cult and its consequences", in which he raised the issue of repressions and terror in Stalin's times. The text of the report itself was not published in the press, but was heard and discussed by the party members and the non-party activists at their meetings.

The shock from the information, voiced by N. Khrushchev, made the state authorities and security services fear of spreading the opposition sentiments. Moreover, the party officials were confused for a long time and did not know how to react to this. Exposing the crimes of I. Stalin this speech at the XX Congress of the CPSU was greeted with approval by the population of Ukraine. This is evidenced by the numerous "information" that the regional party committees sent to the higher authorities. This assessment can be generalised, and applied to the scientific and pedagogical intelligentsia $[5 ; 6]$ shows that the scientific and pedagogical intelligentsia assessed the sensational information about the "dark past" also approvingly, without falling out of the general context of the public sentiment.

The sentiment of the teachers was directly or indirectly transferred to the students. The young people could resort to any hooligan actions under the influence of negative information about J. Stalin (for example, to smash his bust). In case of publicity these and other actions could ruin the reputation of the university or the image of the republic, as a whole. Therefore the authorities monitored the sentiment of teachers in order to know the situation in the students' environment and to be able to influence the young people through them.

The available documents allow to assert that a significant proportion of teachers in the atmosphere of the post-congress diffusion were in a state of confusion. Ivan Rybalka, a lecturer at the Kharkiv State University, recalled that at a closed meeting of the university party organization "the reading of the report continued for several hours, after which at first there was dead silence." He assessed the mood of the audience as "general confusion and some kind of not just suppressed but a direct shock" [7].

On March 31, 1956, the Zhytomyr Regional Committee of the Communist Party informed that among the questions, raised at closed meetings of the primary party organisations, was the following: "How to teach educational material on the history of the party and how to use positions and statements in the teaching and propaganda work?" [8]. The scientific and pedagogical intelligentsia, frightened and 
brought up by the already Soviet power, fearing the negative consequences of the manifestation of initiative and strict responsibility, waited for instructions and tips.

There were also critical speeches that were bold for that time. So, at a party meeting at the Pedagogical Institute, teacher Marchenko expressed an opinion that during the years of Soviet power the Ukrainian culture developed less than in the pre-revolutionary years, that now there are almost no Ukrainian schools, and we have facts when the children cannot study in the Ukrainian language at schools [9]. This is a concrete instance that the results of the XX CPSU Congress and J. Stalins criticism were perceived as a manifestation of a turn towards real glasnost, democracy, etc.

In many speeches it was mentioned about numerous outrages all around. At the Poltava Pedagogical Institute the issue how the decisions of the XX Congress of the CPSU were implemented turned into criticism of the director M. Semivolos whose "cult" at the institute was seen by some of his subordinates. The attempt to remove the director ended without result [3].

Without questioning the criticism in the statements of the intelligentsia, in general, in our opinion, the sentiment of the intelligentsia (including the scientific and pedagogical) did not differ much from the mood of the other professional and social groups. Among workers, engineers and others one can find quite accurate and fair assessments of N. Khrushchev's speech at the XX Congress of the CPSU. However, there is a reason to assert that the scientific and pedagogical intelligentsia did not become the nucleus of the resistance movement.

Despite the general expectations of democratisation of the social and political life, one had to be careful in statements. The party was in a somewhat confused state, but it did not lose control of the situation. Sharp criticism of the incumbent leaders could mean dismissing from one's work. When, at a meeting at the Kharkov State University, a graduate student of the Department of Political Economy directly blamed the members of the Politburo of the CPSU Central Committee for the miserable life of the peasants on collective farms because of the personality cult, he was expelled from the postgraduate studies and could not find a job anywhere else [7].

However, the totality of such criticisms of discontent pretty frightened the authorities. One of the party recommendations stated: "In the cities of Kiev, Kharkov, Odessa, Lvov, Dnepropetrovsk, Stalino, where a large number of universities are concentrated, to hold city meetings of the party activists and meetings of the Komsomol activists of higher educational institutions on the same issue" [10]. Also, it was ordered to hold a meeting of directors of the educational establishments on this topic, to discuss everything at these educational establishments. The Ministry of Higher Education, the Ministry of Education and the Ministry of Culture have pledged to hold 10-day seminars for teachers of humanities and discuss issues how to improve the teaching of the subjects. It was ordered to popularise the decisions of the XX Congress of the CPSU. For this purpose the authorities engaged the entire humanitarian intelligentsia - writers, artists, composers, etc.

On June 22, 1956, the CPSU Central Committee issued a decree "On teaching political economy, dialectical and historical materialism and the history of the CPSU at higher educational institutions", which brought amendments into the curricula and programs of the departments of social sciences [11]. The authorities solved the problem of confusion, a certain free-thinking, even dissent by strengthening the regulation of the teachers' activities. The authorities feared that "unauthorisd thoughts" might arise in the minds of the scientific and pedagogical intelligentsia, that a vacuum might form; herefore, in order to prevent this, they increased the load of their work.

The XX Congress of the CPSU left an impact opon the socio-political atmosphere in the country. It brought in changes that were inherently positive, yet their implementation was difficult and painful; and there was still a long way to go to full democratisation.

Yuri Kurnosov remarked that, first of all, the artistic intelligentsia participated in the Soviet resistance movement. "But representatives of the other professional groups of the society, in particular, some scientists and university professors, also showed their critical attitude to various aspects of the Soviet social system, a desire to wake up the nation (several people were arrested)" [1]. According to the researcher, thousands of people showed their protests in various forms; out of 530 people involved in one way or another in the Ukrainian resistance movement the scientists accounted for $13 \%$ (or 68 people), the writers $11 \%$ (or 58 people), the artists $7 \%$ (or 35 people) [1]. The teachers in a separate group are not selected. Most of all (37\% or 195 people) were engineers, doctors, teachers and journalists. 
"Therefore," sums up Yuri Kurnosov, "the resistance movement was represented mainly by the intelligentsia" [1].

There were collected archival data and analysis made of the quantitative composition of the scientific and teaching intelligentsia in the so-called "Resistance Movement" that took place in Ukraine in this historical period. Using Yuri Kurnosov's data (1994), according to which the number of persons who took part in it and who were officially recorded by the authorities of Ukraine, is more than 500 teachers, scientists and representatives of other groups of the intelligentsia, we have built a graph, showing the participation groups of intelligentsia in the dissident movement (Fig. 1).

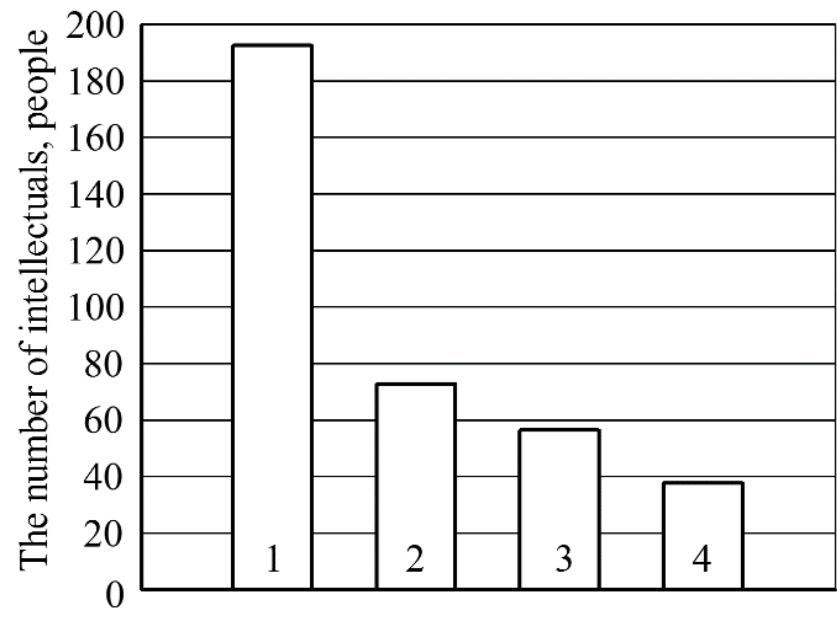

Fig. 1. Participation of intelligentsia in dissident movement in Ukraine

during the "Thaw" period, 1956-1960: 1 - engineers, doctors, teachers, journalists; 2 - scientists; 3 - writers; 4 - artists

As it is evident from the presented graphs, the largest number of those who took part in the dissident movement in Ukraine belong to the group, which included engineers, doctors, teachers and journalists. It is because this particular group of the intelligentsia of Ukraine was at that time the most numerous in the country and, most likely, was not endowed with significant material benefits, positions, privileges in improving their living conditions (apartments), etc. The writers and artists in this historical period took part in the dissident movement with the smallest number of their representatives. This is due exactly to the fact that their activities were under the tireless "supervision" or "pressure" of the authorities. In addition, apparently the order for their professional products was made directly by the authorities of Ukraine and, without any doubt, it brought higher material benefits in the future.

We have also investigated the political attitude of the engineering and pedagogical staff of higher educational institutions and other groups of the intelligentsia in Ukraine and determined the structure of the representatives of individuals participating in the dissident movement (Fig. 2).

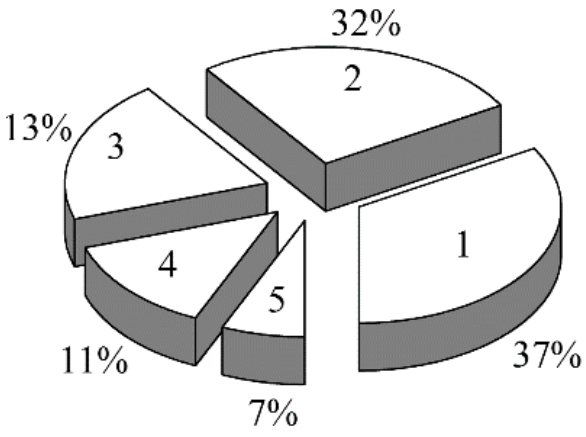

Fig. 2. Structure of representatives of persons participating in protest movements in Ukraine: 1 - engineering and teaching staff; 2 - representatives of other social groups (workers, technicians, service personnel); 3 - scientists of the research and educational institutions;

4 - poets and writers; 5 - artists, architects 
As it is evident from this graphic interpretation, the largest number of persons participating in the protest movements in Ukraine in this historical period also belong to the engineering and pedagogical staff of the higher and secondary educational institutions, as well as the vocational schools, etc. The representatives of the creative professions had the smallest number of people in these dissident protests and public actions. The reasons are the same as indicated above.

In 1956 there took place other important events on a European scale that were of interest to the intelligentsia and citizens of Ukraine. At the end of June riots broke out in Poland with social and political slogans. The revolution in Hungary in October also contained a demand for democratic changes. Although these riots were fiercely suppressed, they left a mark on the worldview of the Soviet intelligentsia. These events were actively discussed in Ukraine; therefore, the government executed monitoring of the sentiments of the population, including the intelligentsia. However, in the assessment of the foreign events there were also such sentiments, which the authorities characterised as "separate incorrect, anti-Soviet reasoning, utterances". For example, Kolodiy, a senior lecturer at the Lviv Trade and Economic Institute, evaluated the events in Poland as "normal": "The Poles have always been distinguished by a great desire for self-determination and independence. During the 30 years of their independent state they have become accustomed to a different way of life. Even many workers lived better at that time than they do now "[12]. Beilis, associate professor of the Lviv State University, told his colleagues that he listened to the radio broadcasts from Poland. "Judging by the reports, dissatisfaction with our tutelage and interference in the internal affairs has matured in the Polish United Workers' Party" [13].

Tishchenko, a professor of the Kharkiv Institute of Agricultural Mechanization said: "Under Stalin, there was no such story, because he could hold everyone tightly in his hands. Tito, the leader of Yugoslavia, plays an important role in all the recent events. The new government of Hungary is also talking about this ... "[14]. Tishchenko compensated for the veiled criticism of the Soviet leadership by accusing J. Tito, proving himself to be a loyal citizen.

S. Yaroslav, a professor of the Kiev Veterinary Institute, in a narrow circle said: "The declaration of the newly formed Revolutionary Peasant Government says that building socialism in Hungary will follow the path, set by Yugoslavia. The political course, taken by Tito, can prevail not only in Hungary and Poland, but also in other countries of the people's democracies "[14].

Sevbo, an associate professor of the Uzhgorod University, criticizing the Soviet press for insufficiently detailed information about the events in Hungary and the rumors caused by this, said that by this our government once again emphasises its isolation from the people, emphasizes distrust in it [12].

The scientific and pedagogical intelligentsia in Poland, Hungary, Czechoslovakia and other countries of the socialist camp were certainly fully informed about the events taking place in the Soviet Union during this historical period. Liberalisation most likely served for the fact that it was during this historical period (in 1956) that revolutionary events took place in Poland and Hungary. The scientific and pedagogical intelligentsia in these countries undoubtedly took part in the revolutionary events. However, the presence of a contingent of the Soviet troops in these states at first restrained open statements by the scientific and pedagogical intelligentsia in the countries of Eastern Europe in support of the changes that took place during this period in the USSR and, in particular, in Ukraine [2].

Since the majority of teachers had already been re-educated by the Soviet regime and had lost their creative freedom, they did not know how to act in the new realities. However, individual teachers went further in assessing the changes, and some of them rather boldly criticised the authorities. Fearing the spread of opposition sentiments among the teaching staff of universities and a negative impact upon the students' circles, the authorities took up political work to educate the intelligentsia. Democratisation was only of a partial nature, and the party institutions gradually began a successive attack on the "dissent" again.

\section{Conclusions}

Although the decisions of the XX congres of the Comunist Party were very important for the scientific and pedagogical intelligentsia of Ukraine, they were not completely democratic and were not entirely perceived by the society unambiguously. Analysis of the reaction of the workers of higher 
education to this event gives grounds to distinguish three types of their sentiments and behavior. The first group reacted to the exposure of Stalin's crimes as loyal citizens and supported the N. Khrushchev's actions. The second group of the intelligentsia, supporting the intentions to improve the political practice of the USSR, were not satisfied with the available solutions and voiced criticism about the existing order. A part of them required real de-Stalinization. The small third part of the scientific and pedagogical intelligentsia behaved cautiously and perceived the new attitudes very critically and fearfully.

True democratisation and freedom of opinion among the teachers, scientists, and students in Ukraine would come only at the beginning of the 1990s, after the abolition of the leading role of the Communist Party and the collapse of the Soviet Union.

\section{References}

[1] Курносов Ю. А. Инакомыслие в Украине (60-е - I половина 80-х гг. 20 века). Dissent in Ukraine (60s - I half of 80s of the XX century). Institute of the History of Ukraine of the National Academy of Sciences of Ukraine. Kyiv, 1994, pp. 48, 49, 77. (In Russian)

[2] Бажан О. Г. 20 съезд КПСС: восприятие и реакция населения Украины. Украина 20 ст.: культура, идеология, политика. Сборник статей. - Выпуск 10: Хрущевская «оттепель»: предпосылки, реалии, последствия. Материалы «круглого стола». (XX Congress of the CPSU: perception and reaction of the population of Ukraine. Ukraine XX century: culture, ideology, politics. Digest of articles. Issue 10: Khrushchev's "thaw": prerequisites, realities, consequences. Round table materials). Kyiv, 2006. 114 p. (In Russian)

[3] Лукьяненко А. В. Повседневность коллективов педагогических вузов Украинской ССР времен десталинизации (1953-1964 роки): диссертация ... канд. ист. наук: 07.00.01 «История Украины». The daily routine of the collectives of the pedagogical universities of the Ukraine during the de-Stalinization (1953-1964): dissertation ... cand. hist. sciences: Poltava, 2012, pp. 133-135 (In Russian)

[4] Крупина В. F. Социальный портрет номенклатуры. Социальные трансформации в Украине: поздний сталинизм и хрущевская эпоха. Social portrait of the nomenclature (Social transformations in Ukraine: late Stalinism and the Khrushchev era). Kiev: Institute of the History of Ukraine of the National Academy of Sciences of Ukraine) 2015, pp. 518-555. (In Russian)

[5] Central State Archives of Public Associations of Ukraine. Fund 1. Inventory 24. Case 4256. Sheet 10.

[6] Central State Archives of Public Associations of Ukraine. Fund 1. Inventory 24. Case 4255. Sheet 148.

[7] Рыбалка И. К. Такова наша судьба: Страницы жизни моего поколения (This is our destiny: Pages of the life of my generation). Харьков, 1999, $126 \mathrm{p}$.

[8] Central State Archives of Public Associations of Ukraine. Fund 1. Inventory 24. Case 4255. Sheet 155.

[9] Central State Archives of Public Associations of Ukraine. Fund 1. Inventory 24. - File 4256. Sheets 13-14.

[10] Central State Archives of Public Associations of Ukraine. Fund 1. Inventory 24. - Case 4256. Sheet 37.

[11] Central State Archives of Public Associations of Ukraine. Fund 1. Inventory 24. - File 4250. - Sheets 327-351

[12] Central State Archives of Public Associations of Ukraine. Fund 1. Inventory 24. - Case 4250. Sheet $362,363$.

[13] Central State Archives of Public Associations of Ukraine. Fund 1. Inventory 24. - File 4250. Sheets 362-363.

[14] Central State Archives of Public Associations of Ukraine. Fund 1. Inventory 24. - Case 4250. Sheet 390. 